ÇOMÜ Uluslararası Sosyal Bilimler Dergisi 2(4), 81-102, 2017

COMU International Journal of Social Sciences 2(4), 81-102, 2017

\title{
Uluslararası Hukukta Devlet ve Başarısız Devletler: Somali Örneği
}

Kerem BATIR*

\section{Öz}

Uluslararası Hukuk'un esas kişisi devletlerdir. Yüzyıllar boyu uluslararası alanda sadece devletler bulunmuş, uluslararası hukuk devletlerarasındaki ilişkileri düzenleyen hukuk dalı olarak kabul edilmiştir. Modern devlet anlayışı 1648 Westfalya Barış Anlaşmasından sonra kurulan dünya düzeninde ulus devlet olarak anlaşılmaktadır. Ulus Devlet kavramı Avrupa'da ortaya çıkmış, daha sonra bir model olarak tüm dünyaya yayılmıştr. 1960lardan itibaren sömürgelerin bağımsızlık kazanmaları sürecinde de eski sömürgeler için bu model geçerli olmuştur. Sömürge devletlerinin bağımsızlıklarını kazanmaları esnasında devlet olma kriterlerinin tam olarak yerine getirip getirmedikleri incelenmemiş ve kısa bir süre içinde bütün sömürgeler bağımsız birer devlet olarak uluslararası sahneye çıkmışlardır. Ancak bu devletlerin büyük bir çoğunluğu etkin bir devlet yönetimine sahip olmadıkları için geleneksel olarak bir devletin yerine getirmesi gereken yükümlülüklerini tam olarak sağlayamamaktadırlar. Bu durum ilgili ülkelerde iç sorunlara yol açmasının yanında uluslararası alanda da sorunlar doğurmaktadır. Bu devletler küresel terörizm, silah ve insan kaçakçılığı, deniz haydutluğu gibi yasa dışı faaliyetlerin odağı haline gelmekte ve uluslararası barış ve güvenliğe tehdit oluşturmaktadırlar. Bu çalışmada uluslararası hukukta devlet kavramı incelendikten sonra başarısız devletler ele alınacak ve son olarak da başarısız devletler arasında en bilineni Somali'nin durumu değerlendirilecektir.

Anahtar Kelimeler: Devlet, Başarısız Devlet, Self Determinasyon, Yeni Sömürgecilik.

\section{State and Failed State in International Law: The Case of Somalia}

\begin{abstract}
The primary subject of international law is state. For centuries states were the only subjects present in international arena and international law was accepted as the branch of law regulating the relations between states. Modern state is understood as nation-state in the World order founded just after the Westphalian Peace Treaty. The concept of Nation State was emerged first in Europe and expanded throughout the globe as a model. This model was also applicable to the countries who gained independence in the decolonization process of 1960s. During the decolonization process the new states were not examined whether they fulfilled the statehood criteria and within a very short period of time they were in the international stage as independent states. However most of those countries could not fulfil the responsibilities of an ordinary state provided that they did not have effective governments. This phenomenon not only causes internal problems but also external ones. Those states became the source of illegal activities like global terrorism, human trafficking, arms smuggling, sea piracy. They were also posing threat to international peace and security. This study will examine the concept of state and then analyse the failed states and lastly the situation in Somalia, as the well-known example of failed states, will be evaluated.
\end{abstract}

Keywords: State, Failed State, Self Determination, Neo-Colonialism.

* Doç. Dr., İzmir Katip Çelebi Üniversitesi İktisadi ve İdari Bilimler Fakültesi Uluslararası ilişkiler Bölümü, kerem.batir@ikc.edu.tr 


\section{Giriş}

Günümüz dünyasında yüzyıl öncesine nazaran çok daha fazla sayıda devlet bulunmaktadır. I. Dünya Savaşı́nın başlangıcında, 1914 yılında Osmanlı ve AvusturyaMacaristan İmparatorluklarının parçalanma sürecinde dünya üzerinde tanınan 55 ulusal devlet mevcuttu. Bu sayı 1919 yılında 59'a çıkmıştır. II. Dünya Savaşı sonrasında bazı sömürgelerin bağımsızıklarını kazanmaları ile birlikte 1950 yılında bu sayı 69 devlete yükselmiştir. 1960ların başında Afrika'da devletlerin bağımsızlıklarını kazanmaya başlamaları ile sayı 90 olmuştur. 1990larda Asya'da, Afrika'da, Okyanusya'da bulunan sömürgelerin bağımsızlık kazanmaları, Sovyetler Birliği ve Yugoslavya Federal Cumhuriyeti'nin dağılmaları ile birlikte devletlerin sayısı 191 olmuştur. ${ }^{1} 2002$ yılında Doğu Timor'un, 2006'da Karadağ'ın, 2008'de Kosova'nın ve 2011 yılında da Güney Sudan'ın bağımsızlıklarını kazanmaları ile birlikte devlet sayısı 195'e ulaşmıştır.

Özellikle sömürge yönetimleri yerine kurulan ulus devletler sömürge döneminin sınırlarına bağlı olarak kurulmak zorunda kaldıklarından bu devletlerden önemli bir kısmı homojen bir etnik yapıya ve devletin temel fonksiyonlarını yerine getirebilecek ekonomik kaynaklara ve devlet kurumlarında görev alacak yetişmiş insan kaynağına sahip olmadıkları için ciddi sorunlarla baş başa kalmışlardır. 54 Afrika ülkesinin 15'inin denize kıyısının olmadığını ve dış ticaret için komşularına muhtaç durumda olduklarını hatırlatmak, bu ülkelerin içinde bulundukları koşulları bir yönüyle açıklamaktadır.

Afrika'da kurulan devletlerin homojen bir etnik yapıda olmamaları bu devletleri kuruldukları andan itibaren iç savaşlara sürüklemiştir. Bir devlette azınlıkta bulunan bir etnik grubun diğer bir devlette çoğunlukta ve yönetimde olması iç sorunları uluslararası platforma taşımakta, devletlerarasında içişlerine müdahale tartş̧maları alevlenmekte ve bu durum devletler arasında savaşa varan sorunlara sebep olabilmektedir.

Son elli yılda uluslararası toplum da önemli bir değişim sürecine girmiştir. 1648 Westfalya Barış Antlaşması ile kurulan devletlerin egemen eşitliğine dayalı dünya düzeni² sarsılmaya başlamıştır. Uluslararası güç dengesi radikal bir biçimde değişmiş, iki kutuplu dünya düzeninden daha karmaşık bir yapıya, düzensizliğe geçiş yapılmıştır. Bu karmaşık yapı içinde yeni güçlü uluslararası aktörler sahneye çıkmış, ekonomi liberalleşmiş ve serbest ticaret yaygınlaşmıştır. Bu dönemde bireyler ön plana çıkmış, insan haklarına saygı göstermek uluslararası hukuk ilkesi haline gelmiştir. Yine bu dönemde güvenlik riskleri de büyük bir dönüşüm geçirmiş, devletlerarası savaşların yerini daha küçük ölçekli fakat uluslararası aktörlerin karışt̆ğı çatışmalar almıştr.

1 Robert I. Rotberg, The Failure and Collapse of Nation-States: Breakdown, Prevention, and Repair, When States Fail:Causes and Consequences, Robert I. Rotberg(Eds.), Princeton University Press, Princeton-2003, s.2.

2 Otuz Yıl Savaşlarını sona erdiren Westfalya Barış Antlaşması Avrupa siyasal düzeni için iki temel ilke getirmiştir. Bunlardan birincisi imperator in regno suo - kral kendi ülkesi sınırları içinde hükümdardır, ikincisi ise cuius regio eius religio - bölge kime aitse onun dini geçerli olacaktı. Antlaşma devletleri belli bir toprak parçası üzerinde üstün yargı yetkisine sahip bağımsız birimler olarak kabul etmiş ve uluslararası hukuk altında eşit muamele görme haklarının olduğu belirtilmiştir. Stewart Patrick, Weak Links: Fragile States, Global Threats, and International Security, Oxford Scholarship, Oxford-2011, S.24. 
Yaşanan bu değişikliklerin ulus devletler üzerinde de etkileri olmuştur. Ulus devletler giderek birbirlerine daha çok karşılıklı olarak bağımlı hale gelmişler (inter-dependence), buna bağlı olarak hem birbirlerine hem de bir bütün olarak uluslararası topluma karşı sorumlulukları artmıştır. Bu dönemde ulus devletlerin vatandaşlarına karşı sorumlulukları da artmış, yeni nesil yönetim anlayışı (yönetişim) ortaya çıkmıştır.

Elbette dünyadaki bütün devletler bu değişim ile uyumlu davranış sergileyememektedirler. Soğuk Savaş döneminde bir bloğa mensup olarak o bloğun lider devletinin koruması ve ekonomik desteği ile ayakta kalmaya çalışan bazı devletler Soğuk Savaş dönemi sona erip koruma ve destekler sona erince mevcudiyetlerini sürdürmekte büyük sıkıntılar içine girmişler, istikrarsızığa ve iç çatışmalara sürüklenmişlerdir. Bu devletler uluslararası topluma karşı yükümlülüklerini de yerine getirmekten aciz duruma düşmüşlerdir. Bu devletler kırılgan ya da başarısız devlet olarak tanımlanmaya başlanmışlardır.

Bu çalışmanın ilk kısmında uluslararası hukukta devlet kavramı ve devlet olmanın koşulları üzerinde durulacak daha sonra uluslararası toplumda değişen standartlar konusu ele alınacaktır. Üçüncü kısımda başarısız devlet tanımı üzerinde durulacak son kısımda ise başarısız devlet örneği olarak Somali'nin Soğuk Savaş'ın sonrasında yaşadıkları incelenecektir.

\section{ULUSLARARASI HUKUK AÇISINDAN DEVLET}

Devlet uluslararası hukukun temel taşıdır. Uluslararası hukuk bir hukuk dalı olarak ortaya çıktığında ilk olarak devletler hukuku olarak adlandırılmıştır. II. Dünya Savaşından sonra uluslararası örgütler ${ }^{3}$ de uluslararası hukukun kişileri olarak kabul edilmeye başlandıktan sonra uluslararası hukuk terimi yaygın bir şekilde kullanılmaya başlanmıştır. Devletler uluslararası hukukun en önemli süjesi olma vasıfları$\mathrm{nı}$ halen sürdürmektedirler. ${ }^{4}$

Uluslararası hukuk açısından devlet tanımı Amerikan Devletleri VII. Uluslararası Konferansı'nda kabul edilen 26 Aralık 1933 tarihli Devletlerin Hakları ve Görevleri hakkındaki Sözleşme (Montevideo Sözleşmesi) ile yapılmıştır. ${ }^{5}$ Bugün dahi Montevideo Sözleşmesi'nde yapılan tanım geçerliliğini muhafaza etmektedir. Devletlerin sahip olması gereken nitelikler Sözleşmenin birinci maddesinde "daimi insan toplu-

3 Uluslararası Adalet Divanı́nın 11.04.1949 tarihli Birleşmiş Milletler Hizmetinde Uğranılan Zararların Giderilmesi hakkındaki Danışma Görüşünde Mahkeme Örgütün uluslararası hukuk kişisi olduğunu; uluslararası haklara ve yükümlülüklere sahip olma yeteneğinin ve uluslararası başvuru yoluyla haklarını sağlama yeteneğinin var olduğuna hükmetmiştir. International Court of Justice, Reparation for Injuries Suffered in the Service of the United Nations, Advisory Opinion of April 11th, 1949, I.C.J. Reports, s. 174. http://www.ici-cii.org/files/case-related/4/004-19490411-ADV-01-00-EN.pdf, erişim tarihi: 11.03.2017.

4 Uluslararası kişilik kavramı dar ve teknik olarak değerlendirildiği takdirde sadece devletler ve uluslararası örgütlerin haklarını uluslararası düzeyde koruması imkanının tanındığı bu kavramın kapsamına girdiği kabul edilmektedir. Uluslararası hukukun kişileri terimi geniş yorumlandığında hukusal statüsü kısmen ya da tamamen uluslararası hukuk tarafindan düzenlenen bütün birimler de bu çerçeve içine girmektedir. Bkz., Hüseyin Pazarcı, Uluslararası Hukuk Dersleri II. Kitap, Ankara Üniversitesi Siyasal Bilgiler Fakültesi Yayınları, Ankara-1989, s.4.

5 Convention on Rights and Duties of States, Convention signed at Montevideo December 26, 1933, http://avalon.law.yale.edu/20th century/intam03.asp, erişim tarihi: 12.03.2017. 
luğu, tanımlanmış bir ülke, hükümet ve diğer devletlerle uluslararası ilişkilere girme kabiliyeti" olarak sayılmıştır. Sözleşmenin ikinci maddesinde de federal devletlerin uluslararası hukukun gözünde tek bir kişiliği oluşturduğu da ifade edilmiştir.

\section{1. İnsan Topluluğu}

Devletin sahip olması gereken niteliklerin başında insan topluluğu gelmektedir. Devlet için insan topluluğu sürekli olarak toprakları üzerinde ikamet eden bireylerden oluşur. Sadece belli dönemlerde bir araya gelen ancak daha sonra dağılıp başka devletlere giden kişiler daimi insan topluluğu olma şartını yerine getiremezler. Ancak ana kitle daimi olarak ülke toprakları üzerinde yaşamak kaydıyla ülkeden göç eden bireylerin bulunması şartın yerine getirilmiş olmasına engel teşkil etmez. Ancak ülkede bulunan yabancılar devletin kurucu unsuru olan insan topluluğu içinde sayılmazlar. İnsan topluluğunu oluşturan kişilerin sayısı şartın yerine gelmesi için önemli değildir. Bugün dünya üzerinde nüfusu 1 milyar kişiyi aşan devletler olduğu gibi birkaç bin kişi ile sınırlı devletlerde bulunmaktadır. Yine insan topluluğunu oluşturan bireylerin aynı etnik kökenden gelmeleri de zorunlu bir unsur değildir. Mevcut devletler arasında tek bir etnik kökenden gelenlerin çoğunluğu oluşturduğu insan topluluklarına sahip ülkeler bulunduğu gibi ABD, Avustralya, Kanada gibi çokuluslu devletlerin de mevcut olduğunu hatırlatmak gerekir. İnsan topluluğuna mensup bireyler ile devlet arasındaki yegâne bağ vatandaşlık bağıdır. Bugün pek çok devletin anayasasında bu durum düzenlenmektedir. ${ }^{6}$

\section{2. Ülke}

Devletin sahip olması gereken niteliklerin ikincisi tanımlanmış bir ülkenin mevcut olmasıdır. Devlet ülkesi, "bir devletin egemenlik yetkilerine sahip olduğu yeryüzü parçası" olarak tanımlanabilir. ${ }^{7}$ Ülke üzerinde insan topluluğunun yaşadığı diğer ülkelerle sınırlarla ayrılmış ve aynı hukuk sistemi altında birleşmiş olan bir coğrafi bütünlüktür. Devletin ülkesel bütünlüğü olarak da ifade edilebilecek bu ilkenin uygulanmasında devletlerin tek bir toprak parçasına sahip olmaları zorunlu değildir. Bir devlet Endonezya, Filipinler gibi binlerce adadan oluşabileceği gibi Türkiye gibi iki kıtada toprakları da olabilir. Hatta birleşme öncesi Doğu Almanya toprakları ile çevrili Batı Berlin'in durumunda olduğu gibi topraklarının bir kısmı bir başka devlet tarafindan çevrili de olabilir. ${ }^{8}$ Devletler anayasalarında ülkesel bütünlüklerine ilişkin düzenlemeler yapabilirler. Türkiye Cumhuriyeti Anayasası'nın 3. maddesinde "Türkiye Devleti, ülkesi ve milletiyle bölünmez bir bütündür." şeklinde bir düzenleme varken Endonezya Anayasası'nın 25A maddesinde Endonezya Cumhuriyeti üniter devletinin bir takımada devleti olduğunu, sınırlarının ve haklarının yasa ile düzenleneceği bildirilmiştir. ${ }^{9}$ Bir başa takımada devleti olan Filipinler, Anayasasında detaylı bir ülke tanımı yaparak Filipinler ülkesinin takımadaları oluşturan tüm

6 Örneğin 1982 Anayasa'sının 66. Maddesinde “Türk Devletine vatandaşılı bağı ile bağlı olan herkes Türk'tür" denmek suretiyle "Türk" teriminin etnik bir aidiyet içermediği, vatandaşlık bağı ile bağlı olan herkesin etnik kökeni ne olursa olsun "Türk" teriminin kapsamına girdiği ifade edilmiştir.

7 Melda Sur, Uluslararası Hukukun Esasları, 7. Baskı, Beta Yayınları, İstanbul-2013, s.104.

8 Hüseyin Pazarcl, a.g.e., s.15.

9 Endonezya Cumhuriyeti 1945 Anayasası, http://www.wipo.int/wipolex/en/text.jsp?file id=200129, erişim tarihi:13.03.2017. 
adalar, adaların arasındaki sular, denizaltı alanları, deniz yatağı ve diğer unsurların ülkeyi oluşturduğu belirtilmiştir. ${ }^{10}$

Ülkenin tanımı içine sadece toprak parçası girmez; nehirler, dağlar, ovalar, göller, içsular, karasuları ve tüm bunların üzerindeki hava sahası ile altındaki toprak kesiti ülke kavramının içinde kabul edilmektedir. Ancak ülkenin ana unsuru kara ülkesidir. Kara ülkesi olmadan ne deniz ülkesi ne de hava ülkesi üzerinde hak sahibi olunabilir.

\subsection{Hükümet}

Devletin sahip olması gereken niteliklerden üçüncüsü hükümettir. ${ }^{11}$ Aslında hükümet devletin sahip olması gereken nitelikler arasında merkezde yer alan bir kriterdir. Ülkenin toprak bütünlüğünü sağlayacak, bu topraklar üzerinde yaşayan insanların güvenliğini sağlayacak organizasyon hükümettir. Uluslararası hukukta genel kabul görmüş bir hükümet tanımını bulmak oldukça zordur. Max Weber'in devlet tanımında hükümet şu anlama gelmektedir: "Belli bir toprak biriminde emirlerini uygulatabilmek için meşru güç kullanma tekelini başarılı bir şekilde muhafaza eden idari personeli olan sürekli organizasyona sahip zorunlu bir politik kurum..."12

Max Weber hükümet kavramını güç kullanma tekeli ile açıklarken hükümet kavramının egemenlik ile yakın ilişki içinde olduğunu da hatırlatmak gerekir. Egemenliği içsel egemenlik ve dışsal egemenlik olarak ikiye ayırdığımızda hükümetin ülke sınırları içinde düzeni sağlaması içsel egemenlik, uluslararası alanda uluslararası hukuk kurallarına uygun olarak hiçbir devletten yardımına muhtaç olmadan bağımsız bir şekilde hareket edebilmesi dışsal egemenlik olarak adlandırılabilir.

Hükümet prensip olarak etkin olmalıdır. Ülkesi ve ülkesinde yaşayan insan topluluğu üzerinde etkin kontrole sahip olmalı, tüm yönetsel fonksiyonları etkin bir şekilde icra etmelidir. Etkinlik aynı zamanda hukuki haklara sahip olunduğunun ve hukuki yükümlülüklerin yerine getirilmesine ilişkin kabiliyetin bir delili olarak da kabul edilir. ${ }^{13}$

Hâlihazırda mevcut devletler için hükümet ülkeyi idare eden siyasal yönetim demektir. Mevcut siyasal yönetimlerin şekli konusunda yürürlükte olan bir uluslararası hukuk kuralı yoktur. Sadece Birleşmiş Milletler Şartının 4. maddesinde Birleşmiş Milletler'e üye olabilmek için devletlerin "barışsever" olmaları şartı aranmaktadır. ${ }^{14}$

10 Filipinler Cumhuriyeti Anayasası, http://www.officialgazette.gov.ph/constitutions/1987constitution/, erişim tarihi: 13.03.2017.

11 Burada hükümet kavramının sadece devletin yürütme gücü yani işbaşındaki hükümet olarak tanımlanmaması; parlamento, yargı, silahlı kuvvetler gibi devletin diğer organları ile bölgesel ve yerel yönetimleri de içerecek şekilde anlaşılması gerektiği ileri sürülmüştür. Pablo Moscoso de la Cuba, "The Statehood of Collapsed States in Public International Law", Agenda İnternacional, Ano XVIII, No. 29,2011, s.125.

12 Max A. Weber, The Theory of Social and Economic Organization, Oxford Universtiy Press, Oxford-1947, s.154'den Nakl. Neyire Akpınarlı, A Different International Law Perception of the Absence of Effective Government, Martinus Nijhoff Publishers, Leiden-2010, s.7.

13 Pablo Moscoso de la Cuba, a.g.m., s.125.

14 Madde 4

1. İşbu Antlaşmanın getirdiği yükümlülükleri kabul eden ve bunları yerine getirme konusunda yetenekli ve istekli olduklarına örgütçe hükmedilen tüm diğer barışsever devletler Birleşmiş Milletlere üye olabilirler. 2.Bu koşullara uyan her devletin Birleşmiş Milletler üyeliğine kabulü, Güvenlik Konseyi'nin tavsiyesi üzerine Genel Kurul kararı ile olur. 
Birleşmiş Milletler hükümetlere ilişkin birkaç kez karar vermek durumunda kalmıştrr. Bunlardan II. Dünya Savaşı sonrası bölünmüş Doğu Almanya (Alman Demokratik Cumhuriyeti) ve Bat Almanya (Almanya Federal Cumhuriyeti)'nın Birleşmiş Milletlere üye olmak istemesi durumudur. Bu soruna pragmatik bir çözüm bulunmuş, her iki Almanya'nın da ayrı ayrı kendi hesaplarına üye olmalarına karar vermiştir. Aynı şekilde 1991 yılında iki Kore'nin de ayrı ayrı kendi hesaplarına üyeliğe kabulü söz konusu olmuştur. ${ }^{15}$

Birleşmiş Milletlerin yaşadığı ikinci büyük sorun ise Milliyetçi Çin (Çin Cumhuriyeti) - Komünist Çin (Çin Halk Cumhuriyeti) sorunudur. II. Dünya Savaşı sonunda 1945 yılında kurulan Birleşmiş Milletlerin beş daimi üyesinden biri de Çin Cumhuriyetidir. Çin Cumhuriyeti'ne karşı Komünistler tarafindan gerçekleştirilen mücadele neticesinde Çin Cumhuriyeti askeri açıdan çökmüş ve Tayvan adasına sığınarak orada yönetimlerini sürdürmeye gayret etmişlerdir. Bu arada tüm Çin anakarası komünistlerin eline geçmiş ve burada Çin Halk Cumhuriyeti kurulmuştur. Bu olayların gerçekleşmesi Birleşmiş Milletler'de Çin'in Çin Cumhuriyeti tarafindan temsil edilmesi durumunu değiştirmemiş yaklaşık 21 yıl boyunca Çin Halk Cumhuriyeti Çin'in meşru temsilcisi olarak görülmemiştir. Ekim 1971 tarihinde Genel Kurul kabul ettiği bir Karar ile Çin Halk Cumhuriyeti delegasyonunu "Çin'in Birleşmiş Milletler nezdindeki tek yasal temsilcisi" olarak kabul etmiştir. ${ }^{16}$

Başarısız devletlerin en temel sorunu olan hükümetin ülkesi ve insan topluluğu üzerinde etkinliğini sağlayamamasının altında yatan temel nedenlerden en önemlisi sömürge dönemini sona erdiren Birleşmiş Milletler Genel Kurulu tarafindan 1960 yılında kabul edilen 1514 sayılı Karar'dır. Bu Kararda bir halkın self determinasyon hakkını kullandığında "siyasi, ekonomik, sosyal ve eğitimsel hazırbulunuşluğunun yetersizliği hiçbir zaman bağımsızlığını ertelemek için bahane olarak ileri sürülemeyecektir"17 denmek suretiyle etkin hükümeti olmayan devletlerin kurulmasının önü açılmıştır. Bu karar Uluslararası Adalet Divanı tarafindan da dekolonizasyon sürecinin temeli olarak kabul edilmiştir. ${ }^{18}$

Bu konuda güzel bir örnek Kongo Cumhuriyetidir. 1960 yılında Kongo Cumhuriyeti kurulduğunda gerçek ve etkin bir hükümeti olmamasına, bağımsızıı için hiçbir hazırlık yapılmamasına, ülkede ayrılıkçı hareketlerin varlığına, merkezi hükümetin ikiye bölünmüşlüğüne ve her iki tarafin da meşru hükümet olduklarını iddia etmelerine rağmen bir devlet olarak kabul edilmiştir. Kongo'nun Birleşmiş Milletler

15 Edward Mc Whinney, Self-Determination of Peoples and Plural-ethnic States in Contemporary International Law, Failed States, Nation-building and the Alternative, Federal Option, Martinus Nijhoff Publishers, Leiden-2007, s.40.

16 United Nations General Assembly, Resolution No. 2758 (XXVI), Restoration of the Lawful Rights of the People's Republic of China in the United Nations, 1976th Plenary Meeting, 25 October 1971, https://documents-dds-ny.un.org/doc/RESOLUTION/GEN/NR0/327/74/IMG/NR032774. pdf?OpenElement, erişim tarihi: 15.03.2017.

17 Declaration on the Granting of Independence to Colonial Countries and Peoples, UN General Assembly Resolution 1514 (XV) of 14 December 1960, para. 3, http://www.un.org/en/decolonization/ declaration.shtml, erişim tarihi: 17.03.2017.

18 International Court of Justice, Western Sahara, Advisory Opinion, I.C.J. Reports 1975, s.12, http:// www.icj-cii.org/files/case-related/61/061-19751016-ADV-01-00-EN.pdf, erişim tarihi: 17.03.2017. 
üyeliği Kongo Cumhuriyetinin egemen haklarına esas alınarak kabul edilmiştir. ${ }^{19}$

Birleşmiş Milletler Genel Kurulu'nun halkların self determinasyon hakkını tanıyan kararından önce devlet uygulaması etkin bir hükümet kontrolünü devletin tanınması için olmazsa olmaz bir koşul olarak kabul etmekteydi. ${ }^{20}$ Kararın kabulünden sonra uygulanması neticesinde halkların self determinasyon prensibi etkin hükümete sahip olmayan devletlerin ortaya çıkmasına sebebiyet vermiştir.

Devletlerin kurulmalarından sonra etkin hükümetlerini kuvvet kullanma nedeniyle kaybetmeleri durumunda devletlerin otomatik olarak lağvedilmeleri sonucunu doğurmamaktadır. II. Dünya Savaşı esnasından Avrupa'da işgale uğrayan devletler birkaç yıl etkin bir hükümetten mahrum kalmalarına rağmen bu devletlerin lağvedilmiş yahut Almanya tarafindan ilhak edilmiş olarak kabul edilmemişlerdir. Benzer bir şekilde 1990 yılında Irak'ın Kuveyt'i işgali ve Kuveyt'i ilhak ettiğine ilişkin deklarasyonu da uluslararası toplum tarafindan Kuveyt devletinin lağvedildiği şeklinde kabul edilmemiş, Birleşmiş Millletler Güvenlik Konseyi tüm devletleri, uluslararası örgütleri ve uzmanlık ajanslarını Kuveyt'in ilhakını tanımamaya ve dolaylı olarak ilhakın tanındığı şeklinde yorumlanabilecek eylemlerden kaçınmaları çağrısında bulunmuştur. ${ }^{21}$

Birleşmiş Milletler son dönemde hükümetleri çökmüş devletlerin egemenliklerine ve toprak bütünlüklerine saygı gösterilmesi için çağrıda bulunmaktadır. Somali'ye ilişkin olarak Güvenlik Konseyi aldığı kararlarda hukuk ve düzenin olmadığını belirttikten sonra Somali'nin egemenliğine ve toprak bütünlüğüne saygı gösterilmesi çağrısında bulunmaktadır. ${ }^{22}$ Benzer bir şekilde Afganistan'la ilgili kararlarında Afganistan'ın egemenliğine, bağımsızlığına, toprak bütünlüğüne ve milli birliğine olan güçlü bağıılı̆ını hatırlatmaktadır. ${ }^{23}$ Etkin hükümete sahip olmayan devletlerin devamlılı̆ı konusundaki kararlıı̆̆ı bu devletlerin Birleşmiş Milletler üyeliklerinin devam ettirilmesinden de anlayabiliriz. Somali'ye ilişkin olarak Somali topraklarının belli kısımlarında ilan edilen Somaliland ve Puntland'ın uluslararası toplumda devlet olarak tanınmamaları da Somali devletinin varlığının devam ettiği şeklinde yorumlanabilir. ${ }^{24}$

\subsection{Uluslararası İlişkilere Girme Kapasitesi}

Devletin sahip olması gereken niteliklerden dördüncüsü ise diğer devletlerle uluslararası ilişkilere girme kabiliyetidir. Bu kriterin içeriği tartş̧ma konusudur. Akpınarlı bu kriteri yeni kurulan devletler ve mevcut devletler açısından ayrı ayrı ele almakta;

19 Pablo Moscoso de la Cuba, a.g.m., ss.126-127.

20 Pablo Moscoso de la Cuba, a.g.m., s.129.

21 UN Security Council Resolution 662(1990) of 9 August 1990, para. 2, http://www.un.org/en/ga/ search/view doc.asp?symbol=S/RES/662(1990), erişim tarihi: 18.03.2017.

22 UN Security Council Resolutions 923(1994) of 31 May 1994 and 954(1994) of 4 November 1994, http://www.un.org/en/sc/documents/resolutions/1994.shtml, erişim tarihi:18.03.2017.

23 UN Security Council Resolutions 1214(1998) of 8 December 1998, http://www.un.org/en/ga/search/ view doc.asp?symbol=S/RES/1214(1998) , 1267(1999) of 24 November 1999, http://www.un.org/ en/ga/search/view doc.asp?symbol=S/RES/1267(1999), 1333(2000) of 19 December 2000, http:// www.un.org/en/ga/search/view doc.asp?symbol=S/RES/1333(2000), erişim tarihi:18.03.2017.

24 Pablo Moscoso de la Cuba, a.g.m., s.157. 
yeni kurulan devletler açısından bu kriterin bağımsızlıkla birlikte tanımlanan dışsal egemenlik olarak yorumlanabileceğini, mevcut devletler açısından ise etkin hükümetin dışsal boyutu olarak yorumlanabileceğini ileri sürmektedir. ${ }^{25}$

Yukarıda açıklanan niteliklerin hepsine sahip olan bir varlık kendiliğinden devlet olur mu sorusu bizleri üzerinde uzun tartışmalar yaşanan tanınma meselesine götürecektir. Tanınma konusunda genel kabul gören iki teoriden birincisi inşacı teori olup bu niteliklere sahip olan varlığın tanınmadıkça devlet olamayacağını ileri sürer; diğeri ise beyan teorisi olup devletin sahip olması gereken niteliklere sahip olan varlıkların başka bir prosedüre gerek olmaksızın devlet olarak kabul edileceklerini, tanınmanın ise sadece bu niteliklere sahip olunduğunun bir beyanı olduğu şeklindedir. Montevideo Sözleşmesinin 3. maddesi tanınma meselesinde bir düzenleme içermektedir. Buna göre devletlerin siyaseten mevcudiyeti diğer devletlerin tanımasından bağımsızdır. Devlet tanınmadan önce de bütünlüğünü ve bağımsızlığını savunma hakkına, uygun gördüğü şekilde kendisini organize etme hakkına, çıkarları doğrultusunda yasama faaliyetinde bulunma hakkına, hizmetlerini yönetme hakkına ve mahkemelerinin yargı çevrelerini ve yetkilerini tanımlama haklarına sahiptir. ${ }^{26}$

Günümüzde genel kabul gören anlayışa göre uluslararası hukuka aykırı bir şekilde kuvvet kullanılarak ya da devletin ülkesel bütünlüğü prensibine aykırı bir şekilde bağımsızlık elde edilmesi hukuken kabul görmezken, kuvvet kullanmayı da içerecek şekilde self-determinasyon hakkının kullanımı neticesinde elde edilen bağımsızlık hukuken kabul görmektedir. ${ }^{27}$ Buna bağlı olarak da ilgili varlığın devlet olarak tanınması ya da tanınmaması gündeme gelmektedir.

Montevideo kriterlerinin güncel uluslararası hukukta geçerliliği konusu doktrinde tartışımaktadır. Jude Vidmar 2013 yılında basılan kitabında Montevideo kriterlerine ilişkin olarak şunları yazmıştr:

... bunlar hukuk normlarından ziyade politika rehber ilkeleridir. Devletler devlet olma kriterleri yerine getirilmeden de tanıma kararı vermeleri, bu kriterler karşılanmış olsa bile tanımadan imtina etmeleri devlet uygulamasının devlet olmanın Montevideo kriterlerine bağlı olduğu kabul etmediklerini göstermektedir. Bu kriterler doğrudan hukuki etki doğurmamaktadır. ${ }^{28}$

Ancak bu görüşe karşı çıkanlar ve Montevideo kriterlerini savunanlar ve hukuki normlar olduklarını ileri süren görüşler de mevcuttur. ${ }^{29}$

25 Neyire Akpınarlı, a.g.e., s.7.

26 Ancak eğer bir Devlet uluslararası hukuk kuralları ihlal edilerek kuruluyorsa bu varlık tanınmadıkça devlet olarak nitelendirilemeyecektir. Buna ilişkin olarak Güney Rodezya örneği verilebilir. 1965 yılında bugünkü Zimbabwe topraklarında ırk ayrımcılığına dayanan lan Smith tarafindan kurulan beyaz azınlık hükümeti Birleşik Krallıktan bağımsızlığını ilan etmiştir. Ancak beyaz azınlığın self determinasyon ilanı meşru bir hareket olarak kabul edilmemiş ve Birleşik Krallık ülkenin meşru yönetimi olarak kabul edilmiştir. 1980 yılında Zimbabwe bağımsızığını ilan ettiğinde yaygın bir şekilde tanınmış ve Birleşmiş Milletlere yeni üye olarak kabul edilmiştir. Mario Silva, State Legitimacy and Failure in International Law, Brill Nijhoff, Leiden-2014, s.41.

27 Yücel Acer ve İbrahim Kaya, Uluslararası Hukuk Temel Ders Kitabı, 5. Baskı, Seçkin Yayınları, Ankara-2014, s.122.

28 Jure Vidmar, Democratic Statehood in International Law, The Emergence of New States in Post-Cold War Practice, Hart Publishing, Oxford-2013, s.241.

29 Dapo Akande, The Importance of Legal Criteria for Statehood: A Response to Jure Vidmar, EJIL Analysis, 7 August 2013, https://www.ejiltalk.org/the-importance-of-legal-criteria-for-statehooda-response-to-jure-vidmar/, erişim tarihi: 15.03.2017. 
Bu kriterler arasında başarısız devletler açısından en önemli eksiklik hükümetin ülke içinde etkinliğinin olmaması ya da oldukça düşük seviye olmasıdır. Bunun sonucu olarak hükümetle rekabet eden başka güç odaklarının ortaya çıkmakta ve bunların arasında bir mücadele yaşanması neticesinde devlet yıkıma sürüklenmektedir.

Devlet olma kriterlerini ele aldıktan sonra devletlerin nasıl başarısız devlet haline geldikleri incelenecektir.

\section{BAŞARISIZ DEVLET}

\subsection{Başarısız Devlet Tanımı}

"Başarısız Devlet" terimine ilk kez Gerald Helman ve Steven Ratner tarafindan 1993 yılında yazılan bir makalede yer verilmiştir. Yazarlar bu tabiri "uluslararası toplumun bir üyesi olarak kendini idame ettirmekten tamamen acze düşmekte olan" ${ }^{30}$ devlet olgusunu tanımlamak için kullanmışlardır. Böyle bir hale düşmenin neticesinde, siyasi istikrarsızlık ve savaşlar yoluyla ilgili devlet hem kendi vatandaşlarını hem de uluslararası toplumu tehdit eder bir duruma gelmektedir.

1990lı yıllar boyunca zayıf ve başarısız devlet kavramı uluslararası güvensizlik ve geleneksel olmayan güvenlik tehditleri ile bağlantılı olarak kullanılmıştır. Helman ve Ratner zaten bu olguyu başarısız devletlerin güvenlik etkilerine dikkati çekmek için ortaya atmışlardır. 11 Eylül saldırılarından sonra saldırıları gerçekleştirenlerin saklandıkları ülkelerin güçsüz merkezi yönetimlere sahip başarısız devletler olduğu ortaya çıkınca ABD başarısız devletlerin yarattı̆ı güvenlik tehdidi ile karşı karşıya kalmıştır. ${ }^{31}$

Başarısız devlet Pottertarafindan "fonksiyonel bir hükümetiolmayan, kurumlartarafindan kuvvet kullanımını kontrol altında tutamayan, vatandaşları için güvenlik sağlayamayan ve sınır güvenliğini sağlayamayan devlet" olarak tanımlanmıştr. ${ }^{32}$ Rotberg güçlü devletlerin tüm yetki seviyelerinde iyi performans gösterdiklerini, kendi topraklarını kontrol edebildiklerini ve vatandaşlarını korkudan uzak tutarak güvenlik sağlayabildiklerini belirtmiştir. Ona göre güçlü ya da faal devletler siyasi özgürlük ve insan haklarına saygı, hukukun üstünlüğünü sağlayabilirler. Faal devletler uluslararası sistemin temel taşları olduğundan başarısız devletler uluslararası ilişkilerin temel yapısını tehdit eder niteliktedirler. Bir devletin başarısızlığı yoksulluk, açıık, şiddet, mülteciler gibi insani krizler yaratma potansiyelini de beraberinde getirdiği için komşu devletleri, bölge devletlerini ve tüm dünyayı etkileyen sonuçları vardır. ${ }^{33}$ Kısaca başarısız devlet hukuken devlet olma niteliğine haiz fakat devletin yetkilerini icra etmekte aciz olarak tanımlanabilir.

30 Gerald B. Helman and Steven Ratner, "Saving Failed States", Foreign Policy, No.89, Winter 92/93, s.3.

31 Matthew A. Slater, "Trumpeting Justice: The Implications of U.S. Law and Policy for the International Rendition of Terrorists from Failed or Uncooperative States", U. Miami International and Comperative Law Review, Vol.12, Summer 2004, s. 152.

32 Donald W. Potter, "State Responsibility, Sovereignty and Failed States", Refereed paper presented to the Australasian Political Studies Association Conference University of Adelaide 29 September-1 October 2004 http://pandora.nla.gov.au/pan/39515/20060719-0000/www.adelaide.edu.au/ apsa/docs papers/Others/potter.pdf , Erişim Tarihi: 16.03.2017

33 Robert I. Rotberg Harvard Üniversitesi Devletiçi Çatışmalar hakkındaki Dünya Barış Vakfi Programı çerçevesinde kırktan fazla ortakla birlikte gerçekleştirdiği 5 yıllık bir projede devletlerin başarısızlıklarını bütün açılardan ele almıştır. Bu çerçevede bir dizi kriter ortaya koyarak devletleri güçlü, zayıf, başarısız ve çökmüş olarak tasnif etmişlerdir. Robert I. Rotberg, a.g.e., ss.5-9. 
Bazı uluslararası hukukçular başarısız devlet teriminin yeni sömürgecilik (neo-colonialism) ile lekelenmiş olduğunu ileri sürerek çağrıştırdığı olumsuz anlam nedeniyle uluslararası hukukta kullanmayı ret etmekte; başarısız devlet terimi yerine "etkin hükümeti olmayan devlet" terimini kullanmayı önermektedirler. ${ }^{34}$ Neyire Akpınarlı başarısız devlet teriminin Somali ile ilgili olarak kullanıma ilişkin yaptığı araştırmada 1990ların başında Birleşmiş Milletler Genel Sekreterleri tarafindan bu terimin birkaç kez kullanıldığını ancak Birleşmiş Milletler Genel Kurulu'nda ya da Güvenlik Konseyi'nde bu terimin hiçbir zaman kullanılmadığını tespit etmiştir. ${ }^{35}$ Bu terim siyaset bilimi açısından uygun bir kullanım olsa da uluslararası hukuk açısından kabulü oldukça zordur. Uluslararası hukuk için "hükümet" devlet olmanın zorunlu unsurlarından biridir. Bir devlet ikiye ya da daha fazla parçaya bölünebilir, başka bir devlet tarafindan işgal edilebilir ya da gönüllü olarak bir başka devletle birleşebilir ya da yeni bir devlet kurabilir. Ancak devlet uzun dönemler boyunca anarşi ve kaos ortamına sahne olsa ya da bir başka devlet tarafindan işgal edilse bile yok olmaz, ortadan kalkmaz. Ancak literatürde yaygın kullanımı nedeniyle bu çalışmada başarısız devlet terimi etkin yönetimden yoksun devlet anlamında kullanılacaktır.

Başarısız devlet kavramının kökenleri araştırıldığında bir önceki bölümde açıklamaya gayret edilen dekolonizasyon sürecinde kendilerini yönetmekten aciz devletlerin self determinasyon hakkı çerçevesinde kurulmasını başlangıç noktası olarak alabiliriz. 1960ların başından itibaren özellikle Afrika kıtasında eski sömürge topraklarında yeni devletler kurulması uluslararası toplumda memnuniyetle karşılanırken esasen kurulan bu devletler Afrika'da sömürge dönemi öncesinden buyana yaşayan yerli halkları temsil eden yapılar olmayıp sömürge döneminde oluşturulan yapının bir devamı niteliğindeydiler. Bu nedenle kurulan devletler başarılı olamadılar, kuruldukları andan itibaren iç savaşlara sürüklendiler. Ancak dönem Soğuk Savaş dönemi idi ve iki kutuplu dünyada süper güçlerin ideolojik nedenlerle yaptıkları silah ve parasal destekleriyle bu devletlerin bütünlükleri korundu. 1990ların başında Soğuk Savaş döneminin sona ermesi, Sovyetler Birliği'nin dağılmasıyla birlikte bu devletlerin yönetimlerine sağlanan silah ve para yardımları da sona erince iç çatı̧̧malar yeniden alevlendi. Bugün itibarıyla Afrika'da pek çok ülkede iç çatışmalar devam etmektedir.

Afrikalı bir hukukçu olan Abdulqawi A. Yusuf Afrika kıtasındaki devletlerin başarısız devlet olarak etiketlenmesini, bu devletlerin manda yönetimlerine ya da Birleşmiş Milletlerin himayesine alınması konusundaki önerilere zemin hazırlamak için ortaya atılmış bir kavram olduğunu iddia etmektedir. Ona göre, pek çok Afrika ülkesinin bağımsızlıklarını kazandıkları 1960lardan bu yana kendi vatandaşlarının temel sosyal hizmetlerini ve güvenliklerini sağlamayı başaramadıkları bilinen bir durumdur. Yapısal zayıflıkları bulunan bu devletlerin gerekli düzeltmeleri gerçekleştiremedikleri takdirde devletlerin çökeceği ya da hükümetlerin etkinliklerini kaybedecekleri görülmektedir. Bu durumdaki devletlerin BM yönetimi ya da himayesi altına alınması koloniciliğin geri dönüşü olarak algılanacaktır. ${ }^{36}$

34 Pablo Moscoso de la Cuba, a.g.m., s.146.

35 Neyire Akpınarlı, a.g.e., ss.88-89.

36 Abdulqawi A. Yusuf, "Government Collapse and State Continuity: The Case of Somalia", Italian Yearbook of International Law, Vol.:13, Year: 2003, s.12. 
Gondal ise başarısız devletlerin kazaen ortaya çıkmadıklarını; coğrafi, çevresel ya da dışsal faktörlerin bunlara sebebiyet vermediğini; liderlerin kararlarının, kötü yasaların, zayıf kurumların devlet başarısızlıklarına sebebiyet verdiğini ileri sürmektedir. ${ }^{37}$

\subsection{Başarısız Devletleri Belirlemeye Yönelik Kriterler}

Daniel Thürer 1999 yılında yayınlanan bir makalesinde başarısız devlet kavramını siyasi ve hukuki açılardan inceleyerek bu olguyu karakterize eden üç unsur önermiştir. Bu unsurlardan birincisi coğrafi ve ülkesel boyuttur; başarısız devletler temel olarak içsel kökenli problemlerle ilişkilidir, nadiren sınır aşan etkileri olur. Güç ve otorite yapıları dışa doğru değil içe doğru bir çöküş yaşar ve dağılma değil daha ziyade çözülme ve yapısal bozulma yaşanır. ${ }^{38}$

İkinci unsur siyasi boyuttur; hukuk ve düzenin içsel olarak yıkılmasıdır. Burada görülen hukuk ve düzeni güvence altına alan yapıların topluca ya da toplamına yakın bir oranda bozulmasıdır. Bu durum iç savaşlarda görülen, devlet içinde kendi pozisyonlarını güçlendirmek ya da devletten ayrılmak için savaşan askeri ya da paramiliter asilerin açıkça belirlenebildiği Devlet otoritesinin bölünmesinden farklı bir durumdur. Üçüncü unsur ise fonksiyonel boyuttur; uluslararası alanda Devleti temsil edecek kapasiteye sahip organların olmayışı ya da olanların da güvenilmez oluşları ve gündüz devlet adamı gece ise eşkıya gibi hareket etmeleri. ${ }^{39}$

Devletlerin başarısız olarak nitelendirilmelerinde hükümetin güç kullanma tekelini kaybedip kaybetmediği büyük önem taşımaktadır. Otoriter bir şekilde yönetilen Kuzey Kore ve Saddam dönemi Irak, Kaddafi dönemi Libya, yönetimlerinin güç tekeline sahip oldukları ve ülke toprakları üzerinde bir noktaya kadar kontrolü sağlayabildikleri için başarısız devletler olarak değerlendirilmemişlerdir. ${ }^{40}$

Silva devletlerin başarısızlığını tanımlamak için on ana kategori önermektedir. Bunlar (1) hukukun üstünlüğünün olmaması, (2) siyasi istikrarsızlık ve meşruiyet yokluğu, (3) yoksulluğa etki eden ekonomik ve sosyal istikrarsızlık, (4) güvenlik yokluğu yahut iç çatışmanın mevcudiyeti, (5) otoriter yönetim ya da kabile sadakati, (6) cezasız bırakma ve etkin olmayan yargı sistemi, (7) iç toprak kontrolünün kaybedilmesi (de jure ve de facto egemenlik), (8) büyük ve sistematik insan hakları ihlalleri, (9) sosyal uyumun ve kalkınmanın yokluğu, ve (10) yolsuzluk ve zayıf ve etkisiz bürokrasi olarak sayılmıştır. ${ }^{41}$

ABD başarısız devletler konusunu takip etmek için 1994 yılında CIA tarafindan finanse edilen Devlet Başarısızlığı Görev Gücü kurmuştur. Bu Görev Gücü veri toplama ve istatistiki metotlarla ilgili danışmanlık veren bilim adamlarından oluşmaktaydı. Görev Gücü 1995 ila 1998 yılları arasında 136 devlet başarısızığı durumunu tespit etti ve devlet başarısızlığını "ciddi siyasi çatışmalar ve rejim krizleri" olarak tanımladı ve

37 Zafar Gondal, "Drafting for a Post Conflict and Collapsed State - The Case of Afghanistan", European Journal of Law Reform, Vol.11, 2009, s.375.

38 Daniel Thürer, "The Failed State and International Law", International Review of Red Cross, Yıl:1999, Cilt: 81, s. 731.

39 Daniel Thürer, a.g.m., s. 731.

40 Erin K. Jenne, "Sri Lanka: A Fragmented State", When States Fail:Causes and Consequences, Robert I. Rotberg(Eds.), Princeton University Press, Princeton-2003, s.219.

41 Mario Silva, a.g.e., s.45. 
"merkezi siyasi otoritenin tümden çökmesi yada çökmeye yaklaşması" olarak kategorize etti. Devlet başarısızığına yol açan olayları da "devrimci savaşlar, etnik savaşlar, muhalif rejim değişiklikleri, soykırımlar ve siyasi kırımlar" olarak ele almışlardır. ${ }^{42}$

Ramcharan 1960lı ve 1970li yıllarda bağımsızlıklarını kazanan eski sömürgelerin keyfi olarak çizilmiş sömürge sınırları içinde var olma mücadelesi verdiklerini, bu nedenle meydana gelen bazı devlet başarısızlığı örneklerine sempati ile yaklaşmanın mümkün olduğunu; devlet başarısızlıklarından söz etmek yerine sömürgecilik ve Soğuk Savaş dönemlerinin sona ermesinden sonra devlet inşası problemleri üzerine konuşmak gerektiğini ifade etmiş, devletleri başarısızlığa götüren sebepleri ve devletleri bu durumdan kurtarmak için önerdiği tedbirleri sıralamıştı. ${ }^{43}$

\subsection{Başarısız Devlet Endeksleri}

Başarısız devletleri tespit etmek için bazı kuruluşlarca endeksler oluşturulmuş yahut mevcut endeksler başarısız devletlerin durumlarını değerlendirmek için kullanılmıştır. Bu endekslerin başında Birleşmiş Milletler Kalkınma Programı tarafindan hazırlanan İnsani Gelişme Endeksi (HDI) gelmektedir. Güçlü devletler HDI endeksinde iyi performans göstermektedirler. HDI, devletlerin insani gelişme düzeylerini ortalama ömür beklentisi, okur-yazarlık, eğitim ve hayat standartlarını esas alarak sıralamaktadır. ${ }^{44}$ Endeks faal devletlerin barış ve düzeni sağlayabildiklerini fakat başarısız devletlerin bunları sağlayamadığını göstermektedir. ${ }^{45}$

Dünya Bankası tarafindan oluşturulan Ülke Politikası ve Kurumsal Değerlendirme Endeksi devletleri dağıtlacak yardımlar açısından sıralamaya tabi tutmaktadır. Bu endeks "kırılgan devletler"i zayıf kurumları, kötü yönetimi, siyasi istikrarsızlığı olan düşük gelirli milletler olarak kategorize etmektedir. 2007 yılında Dünya Bankası 34 ülkeyi kırılgan devlet olarak belirlemiştir. ${ }^{46}$

Başarısız devletler konusunda en çok bilinen endeks bir sivil toplum kuruluşu olan Fund for Peace tarafindan yapılan sıralamadır. Dünya Bankasının kullandığı faktörlere benzer ögeler kullanılarak hazırlanan Kırılgan Devletler Endeksi 2006 yılından bu yana devletleri en kırılgan olan devletten başlayarak sürdürülebilir düzeyde olanlara kadar sıralamaktadır. En son 2017 yılı endeksinde 178 devlet sıralanmıştır. Listenin başında sırasıyla Güney Sudan, Somali, Orta Afrika Cumhuriyeti, Yemen, Sudan, Suriye, Demokratik Kongo Cumhuriyeti, Çad, Afganistan ve Irak bulunuyorken son

42 Jack A. Goldstone et al., State Failure Task Force Report: Phase III Findings, 30 September 2000, http:// www.raulzelik.net/images/rztextarchiv/uniseminare/statefailure\%20task\%20force.pdf, erişim tarihi: 20.03.2017.

43 Bertrand G. Ramcharan, "UN Policies and Strategies: Preventing State Failures and Rebuilding Societies", Journal of International Law \& International Relations, Vol2(1), 2005, ss. 141-154.

44 Birleşmiş Milletler Kalkınma Programı tarafindan hazırlanan 1990-2016 yılları arasındaki İnsani Gelişim Raporları ve İnsani Gelişim Verileri için Bkz., Birleşmiş Milletler Kalkınma Programı İnsani Gelişim Raporları, http://hdr.undp.org/en/data, erişim tarihi:20.03.2017.

45 Robert I. Rotberg, a.g.e., s.4.

46 International Development Association Operational Policy and Country Services (OPCS) and Resource Mobilization Department (FRM), Operational Approaches And Financing In Fragile States, June 2007, s.2, http://documents.worldbank.org/curated/en/412431468142503865/pdf/400450REPLACEM ENTOFILEOIDA1SecM200710449.pdf, erişim tarihi: 18.03.2017. 
sıralarda ise İsveç, Danimarka, İsviçre, Norveç ve Finlandiya yer almaktadır. ${ }^{47}$

Bu endekslerde yer alan bazı devletler otoriter rejimlere sahip olmalarına karşın başarısız devletler sınıfinda değerlendirilmemektedirler. Örneğin Amerikan işgalinden önce Saddam Hüseyin döneminde Irak başarısız devlet olarak sınıflandırılmazken işgalden sonra ilk on devlet arasına girmiştir. Yine Kuzey Kore'de yaygın olarak yoksulluk ve ekonomik çöküş görülmesine rağmen bu devlet de başarısız devlet olarak sınıflandırılmamaktadır. ${ }^{48}$ Bunun temel nedeni makalenin önceki sayfalarında belirtildiği gibi bu devletlerde güç tekelinin merkezi yönetimin elinde olmasıdır.

\subsection{Başarısız Devletlerin Uluslararası Toplumda Yarattığı Etkiler}

11 Eylül saldırıları sonrasında yayınlanan ABD 2002 Ulusal Güvenlik Stratejisinde 11 Eylül olaylarının Afganistan gibi zayıf devletlerin ulusal çıkarlarına büyük tehlike oluşturabileceği beyan edilmiş; Amerika'nın başarısız devletler tarafindan daha fazla tehdit altında olduğu ifade edilmiştir. ${ }^{49}$ Benzer bir şekilde Avrupa Birliği'nin 2003 güvenlik stratejisi başarısız devletleri alarm veren bir olgu olarak tanımlamıştır. ${ }^{50}$ Birleşmiş Milletler Genel Sekreteri ise 2005 yılında devletlerin kırılgan olması durumunda dünyanın halklarının hakları olan güvenlik, kalkınma ve adaletten faydalanamayacaklarını gözlemlemiştir. ${ }^{51}$

Başarısız devletler genellikle iç çatışmalar ve iç sorunlarla karşı karşıya kalırken bu sorunların yarattğı dışsal etkiler de uluslararası toplumu etkilemektedir. John Yoo başarısız devletler tarafindan yaratılan dışsal etkileri üç kategoriye ayırarak incelemiştir. Birinci kategori sivil halka verilen zarar sonucunda bu insanların ülkeden kaçarak komşu ülkelere sığınmaları neticesinde yaratılan dışsal etkidir. Son dönemde Suriye'de ve bazı Afrika ülkelerinden yaşananlar neticesinde insanların göç ederek uluslararası toplumda yarattkları etki bunun güzel bir örneğidir. ${ }^{52}$

İkinci kategori ulus devlet kurumlarının yıkılması neticesinde etnik ve dini gruplar arasında baş gösteren silahlı çatışmalardır. Ruanda'da devlet kurumlarının çökmesi neticesinde yaşanan soykırım yahut Yugoslavya'nın dağılması sürecinde Sırpların Yugoslavya'nın diğer kısımlarında kontrolü ele alma çabalarının yol açtığı etnik temizlik olayları bu bağlamda değerlendirilebilir. Bu tür iç çatş̧malar benzer etnik ya da dini bölünmelerin olduğu komşu ülkelere de yayılma tehlikesi göstermektedir. ${ }^{53}$ Üçüncü kategori ise 11 Eylül 2001 saldırıları sonrası gündeme gelmiştir. Etkin merkezi hükümeti olmayan devletler terörist örgütlerin serbestçe kaynak bulabildikleri, mensuplarını eğitebildikleri ve saldırılar gerçekleştirmek için üsler ku-

47 The Fund for Peace, Fragile States Index 2017, Global Data, http://fundforpeace.org/fsi/data/, erişim tarihi: 18.03.2017.

48 John Yoo, "Fixing Failed States", California Law Review, Vol.99, 2011, s. 104.

49 Office of the President, The National Security Strategy of the United States of America, September 2002, https://www.state.gov/documents/organization/63562.pdf, erişim tarihi: 18.03.2017.

50 Council of the European Union, European Security Strategy: A Secure Europe in a Better World, 12 December 2003, https://www.consilium.europa.eu/uedocs/cmsUpload/78367.pdf, erişim tarihi: 18.03.2017.

51 U.N. Secretary-General, In Larger Freedom: Towards Development, Security, and Human Rights for All, U.N. Doc. A/59/2005, 21 March 2005, http://www.refworld.org/docid/4a54bbfa0.html, erişim tarihi: 18.03.2017.

52 John Yoo, a.g.m., s.107.

53 John Yoo, a.g.m., s.107. 
rabildikleri anarşi alanına dönüşebilmektedirler. Buralarda hazırlanan teröristler dünyanın her tarafinda terörist saldırılar gerçekleştirebilmektedirler. ${ }^{54}$ Amerikan müdahalesi öncesi Afganistan'da El Kaide serbestçe faaliyet gösterebilmekteydi. DAEŞ iç savaş döneminde Suriye'de ve Irak'ta toprak ele geçirmiş ve bu topraklar üzerinde hakimiyetini ilan etmiştir. Yine Somali'de üslenen El-Şebap Kenya'da terörist saldırılarda bulunabilmektedir.

Bunlar dışında etkin bir merkezi hükümetin olmaması devlet dışı aktörlerin uyuşturucu madde kaçakçılığı, insan kaçakçılığı, kara para aklama ve deniz haydutluğu gibi faaliyetlerde bulunmasını kolaylaştırmakta bu durum da diğer devletlere zarar vermektedir.

\subsection{Başarısız Devletlere Yapılan Uluslararası Müdahaleler}

Başarısız devletlerin uluslararası toplumda yarattı̆ı etkilerle mücadele etmek üzere birkaç başarısız devlete askeri müdahaleler gerçekleştirilmiştir. Bu müdahalelerin bazıları Birleşmiş Milletler çerçevesinde gerçekleştirilmiştir, bir kısmı Birleşmiş Milletler Güvenlik Konseyi'nin yetkilendirmesi ya da onayı ile gerçekleşmiştir, bir kısmı ise hiçbir yetki ya da onay alınmadan tek taraflı eylemler şeklinde gerçekleştirilmiştir. Genellikle askeri imkânları gelişmiş bir büyük devlet koalisyon ortakları ile birlikte bu operasyonları gerçekleştirmiştir. Somali'ye yapılan operasyon bir sonraki kısımda ele alınacaktır.

Haiti'de 1994 yılında Birleşmiş Milletler Güvenlik Konseyi 940 sayılı Karar ile Üye Devletleri çok uluslu bir güç kurarak Haiti'ye müdahale etmek için yetkilendirmiş, Birleşmiş Milletler misyonu (UNMIH) kapsamında ABD önderliğindeki güçler insan hakları ihlallerini önlemek ve demokrasiyi yeniden tesis etme amacıyla müdahalede bulunmuşlar, belli ölçüde başarı kazanmışlardır. ${ }^{55}$ Müdahalenin üzerinden yirmi üç yıl geçmesine rağmen Haiti'nin durumunda bir düzelme olmamış, ülke depremlerle ve kasırgalarla harap olmuş, etkin yönetimler kurulamamış ve Amerika kıtasının en fakir ülkesi olarak kalmaya devam etmiştir. Ülke kırılgan devletler endeksinde en kötüler arasında, 11. sıradadır.

Afganistan'da ise ABD ve NATO üyesi müttefikleri 11 Eylül saldırılarından sorumlu olan El Kaide'yi topraklarında barındıran, destek sağlayan ve ideolojik olarak bağları bulunan Taliban rejimine karşı operasyona başlamış ve 2002 yılında Taliban rejimini yıkarak yerine Taliban dışı unsurlardan oluşan bir koalisyon hükümeti kurmuştur. ${ }^{56}$ Aradan geçen on beş yılda Afganistan istikrara kavuşamadığı gibi Taliban ve diğer radikal grupların tehdidi artarak devam etmektedir.

1970'li yıllarda Tanzanya'nın Uganda'ya yaptığı müdahale ile Vietnam'ın Kamboçya'ya yaptıkları müdahaleler başarısız devletlerden kaynaklanan dışsal etkilere karşı gerçekleştirilen erken dönem eylemler olarak görülebilir. Kamboçya'da

54 John Yoo, a.g.m., s.108.

55 Haiti Müdahalesi hakkında detaylı bilgi için Bkz., Kerem Batır, Humanitarian Intervention in International Law: European Conflicts, VDM Verlag, Saarbrücken-2010, s.115.

56 Afganistan Müdahalesi hakkında detaylı bilgi için Bkz., Kerem Batır, "Soğuk Savaş Sonrası Dönemde Amerikan Müdahaleciliği Ve Uluslararası Hukuk", Yönetim Bilimleri Dergisi, Cilt:9:, Sayı:1, 2011, ss.128-130. 
1975 yılında iç savaş neticesinde Kızıl Kmerler ülke yönetimini ele geçirmişler ve üç yıl içinde ülke nüfusunun altıda biri ila üçte biri arasında olduğu tahmin edilen bir kısmını öldürmüşlerdir. Uluslararası toplumun şahit olduğu en büyük boyutlardaki insan hakları ihlallerinin yaşanmasına karşılık Birleşmiş Milletler hiçbir tedbir almamış, sadece kınamayla yetinmiştir. 1978 yılında komşu ülke olan Vietnam tek başına müdahalede bulunmuş ve Kızıl Kmerlerin kurduğu Pol Pot rejimini devirmiştir. ${ }^{57}$

Uganda'yı sekiz yıl boyunca yöneten İdi Amin döneminde ağır insan hakları ihlalleri yaşanmış, üç yüz binden fazla Uganda vatandaşı hayatlarını kaybetmiştir. Uganda'dan binlerce kişi komşu Tanzanya'ya sığınmış ve neticede Tanzanya 1979 yılında Uganda'ya askeri müdahalede bulunarak İdi Amin rejimini devirmiştir. ${ }^{58}$

Bu iki olay büyük güçlerin ya da bölgesel örgütlerin katılmadığı, başarısız devletin dışsal etkilerine maruz kalan komşu devletler tarafindan gerçekleştirilmiş müdahalelerdir ve uluslararası toplum tarafindan tepkiyle karşılanmamış hatta müdahalelere ilişkin olumlu görüşler paylaşılmıştır.

Bu örneklerin yanında başarısız devletlerin olumsuz dışsal etkiler yaratmasına karşın uluslararası toplumun kayıtsız kaldığı pek çok olay da mevcuttur. 1992 yılından başlayarak Bosna-Hersek'te yaşanan Sırpların uyguladığı etnik temizlik politikaları karşısında başta Birleşmiş Milletler olmak üzere uluslararası toplumun etkin bir müdahalede bulunmayıp sadece seyirci kalması hala net bir şekilde hatırlanmaktadır. Yine 1994 yılında Ruanda'da bir milyon Tutsi'nin ve ılımlı Hutu'nun milliyetçi Hutu'lar tarafindan katledilmesi esnasında hiçbir batılı gücün ülkede uygulanan soykırımı durdurmak için müdahale etmemesi de unutulmamıştır.

Başarısız devletlere müdahalede bulunulsa dahi yapılan müdahaleler o andaki sorunu çözmeyi; iç savaşı ya da insani krizi sona erdirmeyi hedeflediğinden, görünen sorunlar çözüme kavuştuktan ve müdahale bittikten sonra birkaç yıl içinde ülkeler yeniden istikrarsızlığa düşebilmektedirler. Afganistan örneğinde ülkede halen müdahaleci gücün askerleri varken ve ciddi miktarda kaynak harcanmasına rağmen ülkede istikrarlı bir yönetim kurulamamaktadır.

Başarısız devletler uluslararası toplum ve diğer devletler için istikrarsızlık yayan, terör örgütlerine sığınak sağlayan, kitlesel göçler nedeniyle bölgesel barış ve güvenliği tehdit eden yapılar olmakla birlikte bu yapılardan faydalananlar da vardır. Bu ülkelerdeki iç çatışmalar nedeniyle silah ticareti yapanlar, yozlaşmış yönetimlerin ülke dışına çıkarmaya çalıştıkları paraları uluslararası finans sistemine sokanlar, ${ }^{59}$ suç örgütleri devletlerin başarısız olmasından nemalanan grupların başında gelmektedir. Bu nedenle iç çatışmalar devam etmekte ve devletlerin kendi başlarına durumlarını düzeltmeleri nadiren görülebilmektedir.

Birleşmiş Milletler'in kuruluşunda esas alınan ulus devlet ve buna bağlı olarak devletlerin toprak bütünlüklerine ve siyasi bağımsızlıklarına saygı gösterilmesi prensiplerine bağlı kalmaya devam etmektedir. Başarısız devletlerin pek çoğunda

57 Kerem Batrr, a.g.e., s.96.

58 Kerem Batrr, a.g.e., s.97.

59 Başarısız rejimlerin ülke parasını nasıl yurtdışına kaçırdıklarını inceleyen bir çalışma için Bkz., Joel Slawotsky, "Partnering with Despots and Failed Regimes: Rogue Banking as a Primary Violation of International Law", 16 San Diego International Law Journal, Vol.16, 2014, ss. 73-118. 
sömürge döneminde çizilen yapay sınırların oluşturduğu problemler devam ederken bu sınırların yeniden çizilmesine Birleşmiş Milletler karşı çıkmakta ve Somali örneğinde olduğu gibi ülkede uzunca bir süre hükümet olmamasına karşın toprak bütünlüğünü tanımaya devam etmektedir.

\section{BİR BAŞARISIZ DEVLET ÖRNEĞi OLARAK SOMALi}

Somali 1991 yılından 2012 yılına kadar tam 21 yıl boyunca etkin bir hükümete sahip olamamıştır. Dünya'da devlet başarısızlığının bir numaralı örneği olarak gösterilen ülke aynı zamanda dünyanın en fakir ülkelerinden biridir. Somali'de yaşanan iç savaşlar neticesinde iki milyondan fazla Somalili yaşadığı yerleri terk etmek zorunda kalmış, bunlardan 900.000 kişi komşu devletlere sığınmak zorunda kalmışlardır. ${ }^{60}$ Somali silah, uyuşturucu ve insan ticareti gibi uluslararası suç şebekelerinin yasadışı işlerinin merkezi haline gelmiş, başta El-Kaide ve El-Şebap olmak üzere terör örgütlerine ev sahipliği yapmıştır. Somali aynı zamanda uluslararası denizcilik için büyük bir tehdit olan deniz haydutların da yuvası haline gelmiştir.

Bu bölümde Somali Cumhuriyeti'nin kuruluşundan bu yana yaşananlar kısaca özetlenecek ve ardından başarısız devlet olmasının ardında yatan politik-ekonomik nedenler irdelenmeye çalışılacaktır.

Somali Cumhuriyeti 1 Temmuz 1960 tarihinde İtalyan Somaliland ve İngiliz Somaliland sömürgelerinin birleşmesi ile kurulmuştur. Alt milyona yakın bir nüfusa sahip ülkede tüm Somalililer aynı dili konuşmaktaydılar ve hepsi Sünni Müslümanlardı. Ancak ülkede dört büyük aşiret ve bunların altında bölünmüş alt aşiretler mevcuttu. ${ }^{61}$ Bağımsızlığın kazanılmasından sonraki 9 yıl boyunca ülkede parlamenter demokrasi uygulanmış ve seçimler barışçl bir ortamda gerçekleşmiştir. Ülke Afrika kıtasında devlet başkanını seçimler yoluyla değiştiren ilk devlet olarak tarihe geçmiştir. 1967 yılında Cumhurbaşkanı Aden Abdulle Osman Daar'ın yerine Dr. Abdirashid Ali Shermarke yapılan seçimleri kazanarak geçmiştir. Bu seçimler Afrika'da devlet başkanlığının demokratik seçimlerle el değiştirmesinin ilk örneğidir. ${ }^{62}$ Cumhurbaşkanı Shermarke'nin Ekim 1969'da öldürülmesini takip eden günlerde General Muhammed Siyad Barre darbe yapmış ve askeri diktatörlük kurmuştur.

Siyad Barre'nin yönetimi boyunca baskıcı bir rejim kurmuş, aşiretlerin birbirlerine olan düşmanlıklarını kullanarak iktidarını korumuştur. Bu dönemde ülkede ilk iç savaş 1977-78 yıllarında yaşanmış ve Barre ordusu muhalifleri bozguna uğratmıştr. 1980lere gelindiğinde ülkede faaliyet gösteren çok sayıda gerilla grubu bulunmaktaydı. ${ }^{63}$ Siyad Barre'nin otoriter yönetimi 21 yıl sürmüştür. 1990 yılına gelindiğinde ülkenin bazı bölgeleri değişik gerilla gruplarının denetimi altına girmişti ve gruplar Siyad Barre rejimine karşı birleşerek ülkenin başkenti olan Mogadişu'yu

60 Bu kişilerden 308,700 kişi Kenya'da, 255,600 kişi Yemen'de ve 246,700 kişi de Etiyopya'da sığınmacı konumundadırlar. United Nations High Commissioner for Refugees, Somalia Situation 2017, Supplementary Appeal, January-December 2017, s.6., http://www.unhcr.org/591ae0e17.pdf, erişim tarihi: 10.05.2017.

61 Chiara Giorgetti, a.g.e., s.23.

62 The Unforgettable History Somalia, October 2010, http://allafrica.com/view/photoessay/user/ user/id/201010280001.html\#1, erişim tarihi:15.05.2017.

63 Abdulqawi A. Yusuf, a.g.m., s.13. 
düzenledikleri ortak saldırılarla ele geçirdiler. 26 Ocak 1991'de Siyad Barre'nin Mogadişu'dan kaçmasıyla birlikte Siyad Barre rejimi de sona ermiş fakat ülke büyük bir kaosun içine sürüklenmiştir.

Diktatörlüğün devrilmesinden sonra başkenti işgal eden grupların militanları sivil halktan binlercesini katletmiş, kamuya ve özel kişilere ait malları ve ülkenin altyapısını talan etmişlerdir. Barre'yi devirenler kısa bir süre sonra ikiye bölünmüşler; General Muhammed Farah Aidid ile Ali Mehdi liderlikleri altında birbirleriyle savaşmaya başlamışlardır. Çatışmalar tüm ülke sathına yayılmış ve sivil halkı çok ciddi bir biçimde etkilemiştir. Tarım arazilerinin talan edilmesi neticesinde ülkede kıtlık ve açlık baş göstermiştir. ${ }^{64}$

1991 yılının Temmuz ayında kurulan Ömer Arteh-Ali Mehdi hükümeti aşiretler arasındaki iç savaş çıkmasını engelleyememiş, Birleşmiş Milletlere başvurarak acil toplant talep etmiştir. Bu talep neticesinde Güvenlik Konseyi toplanarak bir dizi karar kabul etmiştir. Birleşmiş Milletler Somali'ye taraflar arasındaki ateşkesi denetlemek ve acil insani yardım ulaştırmak için UNOSOM'u (United Nations Operation in Somalia - Birleşmiş Milletler Somali Operasyonu) kurmuştur. Bu dönemde misyonda görev yapan askerlere ve insani yardım görevlilerine gerçekleştirilen saldırılar neticesinde ABD komutasında UNITAF (Unified Task Force - Birleşik Görev Gücü) kurulmuş ve bu güce kuvvet kullanma yetkisi verilmiştir. Daha sonra UNITAF tarafindan başlanan barışın, istikrarın, hukuk ve düzenin inşası görevini tamamlamak üzere kurulan Birleşmiş Milletler UNOSOM II operasyonu kapsamında Somali'nin idari ve yargı sistemlerini yeniden kurmaya çalışmıştır. Birleşmiş Milletlerin bu çabaları Mogadişu'da bulunan savaş ağalarının eylemleri karşısında işlevsiz kalmıştir. UNOSOM II operasyonunda görev yapan Pakistan, Nepal ve Amerikan askerlerinin bu güçler tarafindan öldürülmelerinden sonra Somali'deki Birleşmiş Milletler operasyonu 31 Mart 1995 tarihinde sona erdirilmiştir. ${ }^{65}$

1991-1995 yılları arasında UNOSOM I ve II operasyonları kapsamında bir deniz gücü de görev yapmış ve Somali açıklarından geçen önemli deniz yollarının güvenliğini sağlamıştır. Ancak Birleşmiş Milletler operasyonlarının 1995 yılında sona ermesinden sonra bölgede denizleri kontrol edecek ve deniz güvenliğini sağlayacak hiçbir güç kalmamıştır.

2004 yılında Kenya'da geçiş dönemi parlamentosu toplanmış ve Somali Geçici Federal Hükümeti Başkanı olarak Abdulhadi Yusuf seçilmiştir.

1995 yılından 2007 yılına kadar Etiyopya dışında uluslararası toplum Somali'ye doğrudan müdahalede bulunmaktan kaçınmıştır. ${ }^{66} 2007$ yılı başında Afrika Birliği AMISOM adı altında Somali barış operasyonunu başlatmıştır. Misyonun amacı Somali'nin kırılgan barış sürecine destek vermek, geçici federal hükümete yardımcı olmak ve insanı yardım sağlamak olarak belirlenmiştir. Ancak sahada AMISOM (African Union Mission in Somalia - Afrika Birliği Somali Misyonu) komşu devlet Etiyopya'nın çıkarlarına hizmet eden bir güç olarak görülmüş ve yerel halktan ge-

64 Abdulqawi A. Yusuf, a.g.m., s.14.

65 Kerem Batır, a.g.e., ss. 109-113.

66 Etiyopya'nın 2006 yılında başlayan müdahalesi ülkede kaosun ve istikrarsızlığın derinleşmesinden başka bir işe yaramamış, merkezi ve güney Somali'de insani, siyasi ve güvenlik koşulları giderek kötüleşmiştir. Sonuç olarak Etiyopya Ocak 2009 itibarıyla Somali'den çıkmıştır. Mario Silva, a.g.m., s.559. 
reken desteği alamamışttr. Pek çok Afrika ülkesi Somali operasyonunu çok tehlikeli, çok masraflı ve başarıya ulaşması imkânsız olarak gördüklerinden bu operasyonu desteklememişlerdir. ${ }^{67}$ AMISOM'un görev süresi defalarca uzatılmış, en son Birleşmiş Milletler Güvenlik Konseyi'nin 7 Temmuz 2016 tarihli oturumunda alınan 2297 sayılı Karar ile 31 Mayıs 2017 tarihine kadar görev yapması düzenlenmiştir. ${ }^{68}$

2008 yılından itibaren Somali dünya gündemine deniz haydutluğu olayları ile gelmeye başlamıştır. Özellikle gemi kaçırmalar neticesinde elde edilen fidyenin Somali'de yaşanan iç savaşı finanse etmek üzere harcandığı iddia edilmektedir. ${ }^{69}$ Takip eden yıllarda deniz haydutluğu olayları tırmanışa geçmiş, bu olaylarla baş edebilmek için Birleşmiş Milletler, Avrupa Birliği, ABD ve müttefikleri, Rusya, Çin ve Hindistan Somali açıklarında savaş gemileri ile devriye görevleri icra etmeye başlamışlar ve deniz haydutlarıyla etkin bir mücadeleye girişmişlerdir. ${ }^{70}$

2012 yılında 21 yıl sonra ilk defa Parlamento Mogadişu'da toplanmış ve 2004 yılında kurulan geçici federal hükümet 10 Eylül 2012 tarihinde Hasan Şeyh Mahmud'un Parlamento tarafindan Cumhurbaşkanı seçilmesi ile sona ermiştir. Ocak 2013'e gelindiğinde ABD 1991 yııından beri ilk kez Somali hükümetini tanıdığını açıklamıştır. ${ }^{71}$

Somali'de 2016 yılında seçim süreci başlamış ve Muhammed Abdülhadi Muhammed 8 Şubat 2017 tarihinde Cumhurbaşkanı seçilmiştir. Daha sonra Başbakan Hasan Ali Keyre tarafindan kurulan bakanlar kurulu 29 Mart 2017 tarihinde parlamentodan güvenoyu alarak göreve başlamıştır. ${ }^{72}$

Son dönemde yaşanan gelişmelere rağmen ülkenin parçalanmış durumu devam etmektedir. Ülkenin kuzeyinde bağımsızlık ilan etmiş (ancak uluslararası toplum tarafindan tanınmamış) Somaliland kendi ordusuna ve polis teşkilatına sahiptir ve sınırlarını korumaktadır. Yarı otonom statüdeki Puntland da kendi ordusunu ve polis gücünü kurmuştur. Bu iki bilinen bölgesel yönetim dışında Galmudug Geçici Yönetimi ve Jubbaland Geçici Yönetimleri de kurulmuş, çoğunluğu aşiretlerin silahlı üyelerinden oluşan kendi güvenlik güçlerini oluşturmuşlardır. Somali merkezi yönetiminin de sayıları 10.000 civarında olan silahlı kuvvetleri ile 5.000 civarında olan polis gücü bulunmaktadır. Ancak ordu mensuplarına düzenli maaş ödenemediği ve aşiret bağları nedeniyle merkezi yönetimin kontrolünde bulunan bölgelerde dahi güvenliği sağlayamadıkları görülmüştür. ${ }^{73}$

67 Paul D. Williams, "Into the Mogadishu Maelstrom: The African Union Mission in Somalia", International Peacekeeping, Vol.:16, No:4, 2009, ss. 514-530.

68 Güvenlik Konseyi Kararında Somali'deki durumun Birleşmiş Milletler Barışı koruma misyonu görevlendirmek için uygun olmadığını belirtmiştir. United Nations Security Council, Resolution 2297(2016) adopted on 7 July 2016, http://www.un.org/en/ga/search/view doc.asp?symbol=S/RES/2297(2016), erişim tarihi: 16.05.2017.

69 Neyire Akpınarlı, a.g.e., s.49.

70 Somali açıklarında deniz haydutluğu olayları ve uluslararası toplumun mücadele yöntemlerine ilişkin olarak Bkz., Kerem Batır, Yirmibirinci Yüzyılda Deniz Haydutluğu ve Uluslararası Hukuk, Usak Yayınları, Ankara-2011, ss.203-242.

71 BBC News, US Officially Recognises Somalia's Government, 17 January 2013, http://www.bbc.com/ news/world-us-canada-21053071, erişim tarihi: 16.05.2017.

72 Dış İşleri Bakanlığı, Somali'nin Siyasi Görünümü, http://www.mfa.gov.tr/somali-siyasi-gorunumu. tr.mfa, erişim tarihi: 16.05.2017.

73 European Asylum Support Office, EASO Counrty of Origin Information Report, Somalia Security Situation, February 2016, ss.15-17, https://coi.easo.europa.eu/administration/easo/PLib/EASOSomalia-Security-Feb2016.pdf, erişim tarihi: 16.05.2017. 
Ekonomik açıdan da Somali'nin durumu pek iç açıcı değildir. Ülkede kişi başına düşen yıllık gelir 2016 yılında 450 ABD Doları civarındadır. 2012 yılından bu yana kamu gelirleri ve harcamaları artş göstermekte olsa da kamusal gelirler 2015 yılında 115 milyon ABD Doları seviyesinde olup vatandaşlara yeterli kamu hizmetlerini sağlayacak düzeyden çok uzaktadır. Elde edilen kamusal gelirin \%85'i idari ve güvenlik için harcanmakta, ekonomik ve sosyal sektörler bütçeden sadece \%10 pay alabilmektedir. Uluslararası toplumun vadettiği yardımlardan 2015 yılında sadece \%32'si gerçekleşmiş olup bu durum merkezi hükümeti zora sokmaktadır. ${ }^{74}$

\section{SONUÇ}

Başarısız devletler sorunu Avrupa'da ortaya çıkan ulus devlet modelinin uluslararası sistemin temel unsuru olarak alınıp aynı modelin bağımsızlığını kazanan sömürgelere de uygulanmasının neticesinde ortaya çıkan bir durumdur. "Cetvelle çizilmiş" sömürge sınırları yerel halkın gerçek sınırları olmadığından bu sınırlar içinde yaşayan farklı etnik kökenlere mensup insanlar bir araya gelerek millet bilinci oluşturamamış, ülkeleri yönetenler ise bağımsızlıkların kazanılmasından itibaren ülke toprakları üzerinde etkin bir yönetim kuramamışlardır. Bugün başarısız devlet olarak nitelendirilen devletlerin büyük bir çoğunluğunun Afrika'da ve Orta Doğu'da bulunan eski sömürgeler olmaları dikkatlerden kaçmamalıdır.

Başarısız devletler sorununu çözebilmek için bugüne kadar gerçekleştirilen askeri müdahalelerin sonuçlarına baktı̆ımızda askeri müdahale gerçekleştirilen yerlerde müdahaleden sonra iç çatş̧malar bir ölçüde bitse yahut azalsa dahi bu devletlerin istikrara kavuşamadıkları ve başarısız devlet olmaya devam ettikleri görülmüştür. Sadece Kosova örneğinde yapılan müdahale neticesinde yeni bir devlet ortaya çıkmış ve müdahale sonrası çatışma ortamı devam etmemiştir.

Bazı batılı yazarlar başarısız devletler sorununun çözümü için ulus devlet modeli dışında çözümler önermektedirler. Bu devletlerde yaşayan her etnik gruba kendi yönetimini kurma hakkının tanınması böylece daha yönetilebilir devletçikler oluşturulması önerilmektedir. Ancak bu durum ayrılıkçı hareketleri cesaretlendirebilir, bugün için istikrarlı olan başka devletlerin yapılarını da bozabilir. Bu nedenle devletlerin toprak bütünlüklerini tehlikeye atan önerilerden uzak durulması gerekir.

Yine bazı batılı yazarlar da başarısız devletlerin ilk kuruldukları andan itibaren etkin bir yönetime sahip olamamalarından hareketle bu devletlerin Birleşmiş Milletler Vesayet Meclisi'nin denetimine verilmesi ya da buna benzer bir vesayet sistemi kurularak bu devletlerin kendi kendilerini yönetme kabiliyeti kazanana kadar uluslararası gözetim altında olmalarını önermektedirler. Bu öneri yeni sömürgecilik (neo-colonialism) olarak algılanmakta ve özellikle Afrikalı hukukçular tarafindan eleştirilmektedir. Ancak burada sömürge döneminden farklı olarak tek bir devletin gözetimi değil uluslararası bir örgüt olan Birleşmiş Milletlerin şemsiyesi altında uluslararası bir gözetimden bahsedilmektedir. Somali örneğinde görüldüğü gibi mevcut durum sürdürülebilir olmaktan çok uzaktır. Bu nedenle başarısız devletlerin desteklenmesi ve yapılarının güçlendirilmesi için yol gösterici bir uluslararası mekanizmanın kurulması yerinde olacaktır.

74 Dünya Bankası, Somalia, http://www.worldbank.org/en/country/somalia/overview , Erişim tarihi: 15.05.2017. 
Batılı devletlere çıkarları doğrultusunda hareket ettikleri, yeralt kaynakları zengin ülkelere müdahale ettikleri, fakir ülkelerde yaşanan insanlık trajedilerine gözlerini kapattıkları eleştirisi her daim yapılmaktadır. Bu eleştiride büyük bir haklılık payı olmakla birlikte Somali, Kosova ve Afganistan örnekleri bize göstermiştir ki bu ülkelere yapılan müdahaleler bu ülkelerdeki doğal kaynaklar için değil, bu ülkelerin dünya barış ve güvenliğine olan kötü etkileri nedeniyle gerçekleşmiştir. $A B D$ ve müttefikleri bu operasyonlara milyarlarca dolar harcamışlar, karşılığında ise maddi bir menfaat elde edememişlerdir. Petrol zengini Irak'ın işgali bile ABD için ağır bir külfet getiren operasyon olmuştur.

Uluslararası terör ve suç şebekeleri ile mücadele için başarısız devletlerin rehabilite edilip kendi kendilerini yönetmeleri ve sınırlarını kontrol etmelerinin sağlanması çok önemlidir. Bugüne kadar müdahale ile yahut sadece insani yardım gönderilerek bu başarılamamıştır. Uluslararası toplumun daha etkin bir yol bulması gerekmektedir. 


\section{KAYNAKÇA}

Acer, Y. ve I. Kaya (2014). Uluslararası Hukuk Temel Ders Kitabı, 5. Baskı, Seçkin Yayınları, Ankara.

Akande, D. (2013). "The Importance of Legal Criteria for Statehood: A Response to Jure Vidmar", EJIL Analysis, 7 August 2013, https://www.ejiltalk.org/the-importance-of-legal-criteria-for-statehood-a-response-tojure-vidmar/, erişim tarihi: 15.03.2017.

Akpınarlı, N. (2010). A Different International Law Perception of the Absence of Effective Government, Martinus Nijhoff Publishers, Leiden.

Batır, K. (2011). "Soğuk Savaş Sonrası Dönemde Amerikan Müdahaleciliği Ve Uluslararası Hukuk", Yönetim Bilimleri Dergisi, Cilt:9:, Sayı:1, ss.115-134.

Batır, K. (2010). Humanitarian Intervention in International Law: European Conflicts, VDM Verlag, Saarbrücken-2010. Batır, K. (2011). Yirmibirinci Yüzyılda Deniz Haydutluğu ve Uluslararası Hukuk, Usak Yayınları, Ankara.

BBC News, US Officially Recognises Somalia's Government, 17 January 2013, http://www.bbc.com/news/worldus-canada-21053071, erişim tarihi: 16.05.2017.

Birleşmiş Milletler Kalkınma Programı İnsani Gelişim Raporları, http://hdr.undp.org/en/data, erişim tarihi:20.03.2017.

Convention on Rights and Duties of States, Convention signed at Montevideo December 26, 1933, http://avalon. law.yale.edu/20th_century/intam03.asp, erişim tarihi: 12.03.2017.

Council of the European Union (2013). European Security Strategy: A Secure Europe in a Better World, 12 December 2003, https://www.consilium.europa.eu/uedocs/cmsUpload/78367.pdf, erişim tarihi: 18.03.2017.

de la Cuba, P. M. (2011). "The Statehood of Collapsed States in Public International Law", Agenda Internacional, Ano XVIII, No. 29, ss.121-174.

Declaration on the Granting of Independence to Colonial Countries and Peoples, UN General Assembly Resolution 1514 (XV) of 14 December 1960, http://www.un.org/en/decolonization/declaration.shtml, erişim tarihi: 17.03.2017.

Dünya Bankası (2017). Somalia, http://www.worldbank.org/en/country/somalia/overview, Erişim tarihi: 15.05.2017.

Endonezya Cumhuriyeti 1945 Anayasası, http://www.wipo.int/wipolex/en/text.jsp?file_id=200129, erişim tarihi:13.03.2017.

European Asylum Support Office (2016). EASO Counrty of Origin Information Report, Somalia Security Situation, February 2016, https://coi.easo.europa.eu/administration/easo/PLib/EASO-Somalia-Security-Feb2016. pdf, erişim tarihi: 16.05.2017.

Filipinler Cumhuriyeti Anayasası, http://www.officialgazette.gov.ph/constitutions/1987-constitution/, erişim tarihi: 13.03.2017.

Goldstone, J. A. et al. (2000). State Failure Task Force Report: Phase III Findings, 30 September 2000, http:// www.raulzelik.net/images/rztextarchiv/uniseminare/statefailure\%20task\%20force.pdf, erişim tarihi: 20.03.2017.

Gondal, Z. (2009). "Drafting for a Post Conflict and Collapsed State - The Case of Afghanistan", European Journal of Law Reform, Vol.11, ss.369-401.

Helman, G. B. and S. Ratner (1992). "Saving Failed States", Foreign Policy, No.89, Winter 92/93, ss.3-20.

International Court of Justice, Reparation for Injuries Suffered in the Service of the United Nations, Advisory Opinion of April 11th, 1949, I.C.J. Reports, s. 174. http://www.icj-cij.org/files/case-related/4/00419490411-ADV-01-00-EN.pdf, erişim tarihi: 11.03.2017.

International Court of Justice, Western Sahara, Advisory Opinion, I.C.J. Reports 1975, http://www.icj-cij.org/files/ case-related/61/061-19751016-ADV-01-00-EN.pdf, erişim tarihi: 17.03.2017.

International Development Association Operational Policy and Country Services (OPCS) and Resource Mobilization Department (FRM) (2007). Operational Approaches And Financing In Fragile States, http:// documents.worldbank.org/curated/en/412431468142503865/pdf/400450REPLACEMENTOFILEOIDA1S ecM200710449.pdf, erişim tarihi: 18.03.2017.

Jenne, E. K. (2004). "Sri Lanka: A Fragmented State”, When States Fail:Causes and Consequences, Robert I. Rotberg(Eds.), Princeton University Press, Princeton, ss.219-244.

Mc Whinney, E. (2007). Self-Determination of Peoples and Plural-ethnic States in Contemporary International Law, Failed States, Nation-building and the Alternative, Federal Option, Martinus Nijhoff Publishers, Leiden.

Office of the President (2002). The National Security Strategy of the United States of America, September 2002, https://www.state.gov/documents/organization/63562.pdf, erişim tarihi: 18.03.2017. 
Patrick, S. (2011). Weak Links: Fragile States, Global Threats, and International Security, Oxford Scholarship, Oxford-2011.

Pazarcı, H. (1989). Uluslararası Hukuk Dersleri II. Kitap, Ankara Üniversitesi Siyasal Bilgiler Fakültesi Yayınları, Ankara-1989.

Potter, D. W. (2004). "State Responsibility, Sovereignty and Failed States", Refereed paper presented to the Australasian Political Studies Association Conference University of Adelaide 29 September- 1 October 2004 http://pandora.nla.gov.au/pan/39515/20060719-0000/www.adelaide.edu.au/apsa/docs_ papers/Others/potter.pdf, Erişim Tarihi: 16.03.2017

Ramcharan, B. G. (2005). “UN Policies and Strategies: Preventing State Failures and Rebuilding Societies”, Journal of International Law \& International Relations, Vol2(1), ss. 141-154.

Rotberg, R. I. (2004). The Failure and Collapse of Nation-States: Breakdown, Prevention, and Repair, When States Fail:Causes and Consequences, Robert I. Rotberg(Eds.), Princeton University Press, Princeton, ss.1-45.

Silva, M. (2014). State Legitimacy and Failure in International Law, Brill Nijhoff, Leiden.

Slater, M. A. (2004). "Trumpeting Justice: The Implications of U.S. Law and Policy for the International Rendition of Terrorists from Failed or Uncooperative States", U. Miami International and Comperative Law Review, Vol.12, Summer, ss. 151-187.

Slawotsky, J. (2014). "Partnering with Despots and Failed Regimes: Rogue Banking as a Primary Violation of International Law", 16 San Diego International Law Journal, Vol.16, ss. 73-118.

Sur, M. (2013). Uluslararası Hukukun Esasları, 7. Baskı, Beta Yayınları, İstanbul.

The Fund for Peace, Fragile States Index 2017, Global Data, http://fundforpeace.org/fsi/data/, erişim tarihi: 18.03.2017.

The Unforgettable History Somalia, October 2010, http://allafrica.com/view/photoessay/user/user/ id/201010280001.html\#1, erişim tarihi:15.05.2017.

Thürer, D. (1999). “The Failed State and International Law”, International Review of Red Cross, Vol.: 81, ss. 731-761.

Türkiye Cumhuriyeti Dış işleri Bakanlığı, Somali'nin Siyasi Görünümü, http://www.mfa.gov.tr/somali-siyasigorunumu.tr.mfa, erişim tarihi: 16.05.2017.

United Nations Secretary-General (2005). In Larger Freedom: Towards Development, Security, and Human Rights for All, U.N. Doc. A/59/2005, 21 March 2005, http://www.refworld.org/docid/4a54bbfa0.html, erişim tarihi: 18.03.2017.

United Nations Security Council Resolution 1214(1998) of 8 December 1998, http://www.un.org/en/ga/search/ view_doc.asp?symbol=S/RES/1214(1998), erişim tarihi:18.03.2017.

United Nations Security Council Resolution 1267(1999) of 24 November 1999, http://www.un.org/en/ga/search/ view_doc.asp?symbol=S/RES/1267(1999), erişim tarihi:18.03.2017.

United Nations Security Council Resolution 1333(2000) of 19 December 2000, http://www.un.org/en/ga/search/ view_doc.asp?symbol=S/RES/1333(2000), erişim tarihi:18.03.2017.

United Nations Security Council Resolution 662(1990) of 9 August 1990, http://www.un.org/en/ga/search/view_ doc.asp?symbol=S/RES/662(1990), erişim tarihi: 18.03.2017.

United Nations Security Council Resolutions 923(1994) of 31 May 1994 and 954(1994) of 4 November 1994, http://www.un.org/en/sc/documents/resolutions/1994.shtml, erişim tarihi:18.03.2017.

United Nations General Assembly, Resolution No. 2758 (XXVI), Restoration of the Lawful Rights of the People's Republic of China in the United Nations, 1976th Plenary Meeting, 25 October 1971, https://documents-dds-ny. un.org/doc/RESOLUTION/GEN/NRO/327/74/IMG/NR032774.pdf?OpenElement, erişim tarihi: 15.03.2017.

United Nations High Commissioner for Refugees (2017). Somalia Situation 2017, Supplementary Appeal, JanuaryDecember 2017, http://www.unhcr.org/591ae0e17.pdf, erişim tarihi: 10.05.2017.

United Nations Security Council, Resolution 2297(2016) adopted on 7 July 2016, http://www.un.org/en/ga/ search/view_doc.asp?symbol=S/RES/2297(2016), erişim tarihi: 16.05.2017.

Vidmar, J. (2013). Democratic Statehood in International Law, The Emergence of New States in Post-Cold War Practice, Hart Publishing, Oxford.

Weber, M. A. (1947). The Theory of Social and Economic Organization, Oxford Universtiy Press, Oxford.

Williams, P. D. (2009). "Into the Mogadishu Maelstrom: The African Union Mission in Somalia", International Peacekeeping, Vol.:16, No:4, 2009, ss. 514-530.

Yoo, J. (2011). "Fixing Failed States", California Law Review, Vol.99, ss. 95-150.

Yusuf, A. A. (2003). "Government Collapse and State Continuity: The Case of Somalia", Italian Yearbook of International Law, Vol.:13, ss.11-33. 